\title{
Petismo e Chavismo: Variedades de Capitalismo e de Regulação Trabalhista no Brasil e na Venezuela*
}

\section{Wallace dos Santos de Moraes}

Professor-adjunto do Departamento de Ciência Política da Universidade Federal do Rio de Janeiro (UFRJ). Rio de Janeiro, RJ, Brasil. E-mail: wmoraes@ifcs.ufrj.br.

\begin{abstract}
T o início do século XXI, a América Latina (AL) vive uma profunda 1 transformação política. Chegaram ao Poder Executivo, na maior parte dos países da região, governos identificados com um histórico de base popular, ou operária, ou camponesa, ou étnica, apresentando-se como representantes de maiorias excluídas de participação ativa da política e da economia desses países por mais de 500 anos. Assim, vimos um indígena presidente da Bolívia, um ex-operário presidente do Brasil e mulheres governando nações como Chile, Argentina e Brasil. Somados a esses fatos, os casos de Uruguai, Paraguai, Venezuela, Bolívia, Equador, Nicarágua e Guatemala são exemplos do que a literatura chama de "terceira onda de democratização na América Latina" (Hagopian e Mainwaring, 2005; Lanzaro, 2006) ou "maré rosa" (Panizza, 2005).
\end{abstract}

Dentre os modelos em questão, aprofundaremos nossa análise sobre os exemplos brasileiro e venezuelano. São dois casos paradigmáticos. A chegada ao poder do Partido dos Trabalhadores, sobretudo com um ex-operário, seguido por uma mulher, tem um efeito simbólico incomensurável como renovação para as esperanças dos trabalhadores no Brasil.

\footnotetext{
* Agradeço a Luciana Simas, Wanise Cabral e aos pareceristas anônimos de DADOS - Revista de Ciências Sociais pelos comentários.
}

DADOS - Revista de Ciências Sociais, Rio de Janeiro, vol. 57, no-2, 2014, pp. 359 a 397. 
Já na Venezuela, um coronel do Exército e ex-golpista ganhou as eleições de 1998 com a maior margem de votos da história eleitoral do país e se manteve no poder com amplo apoio popular nas ruas e igualmente ampla oposição dos setores de classe média e das elites.

Feito esse breve introito, perguntamos: qual desses governos aumentou os direitos aos trabalhadores? Objetivamos analisar um aspecto central das políticas públicas na América Latina, mais precisamente às relacionadas ao mundo do trabalho. Jogaremos luz sobre o tratamento dado às normas trabalhistas nos dois países nesses primeiros 12 anos do século XXI ${ }^{1}$.

O objetivo desta pesquisa é encontrar respostas para a pergunta supracitada com base em um estudo histórico das relações entre capital e trabalho. Para tanto foi necessário um estudo de longo prazo, do contrário não entenderíamos muitas das questões esdrúxulas que a envolvem. A análise de curto prazo não nos possibilitaria perceber o início da relação. Neste sentido, o conceito de path dependence nos ajudará a compreender de maneira coerente o processo. Daí o entendermos como averiguação de escolhas feitas em determinadas conjunturas que resultam em posições no presente, depois das quais diminuem as possibilidades de trajetórias alternativas, como se existisse uma causalidade social dependente da trajetória percorrida observada na história (Mahoney, 2001; Pierson, 2004). Em outras palavras, path dependence denota que um determinado ator, ou um conjunto de atores, ao escolher um caminho, implica heranças institucionais quase irreversíveis e/ou com altos custos para sua reversão. Ademais, a path dependence pode conter aspectos positivos e negativos.

O artigo está disposto da seguinte maneira: discutimos as determinantes da path dependence da relação capital-trabalho a partir das heranças institucionais deixadas pelas políticas neoclássicas e em seguida analisamos as características do modelo instalado no século XXI para Venezuela e Brasil, respectivamente, sempre perscrutando as leis trabalhistas. Vamos ao primeiro passo ${ }^{2}$.

\section{CAPITALISMO DE LAS CALLES: O CASO DA VENEZUELA}

Escrever sobre a história da relação capital-trabalho na Venezuela requer que levemos em conta cinco aspectos centrais: 1) a enorme dependência econômica do país da extração de petróleo; 2) a parca industrialização; 3) a existência de um empresariado deveras dependente do 
Estado e, em sua maioria, subordinado às multinacionais desde o descobrimento do petróleo; 4) a formação de uma classe trabalhadora pouco atuante e reformista, cuja aristocracia operária esteve ligada ao partido da Acción Democrática (AD); 5) a extrema desigualdade social. Nesta introdução, esboçamos rapidamente a importância destes aspectos para a pesquisa em questão.

A economia venezuelana difere de maneira significativa das demais da América Latina, em particular da do Brasil, o que reflete em uma peculiaridade da relação capital-trabalho. Na quase totalidade das economias do continente, os problemas mais fundamentais são a escassez relativa de capital e a reduzida capacidade para importar. Na Venezuela, historicamente, a situação é praticamente oposta: o sistema tende a afogar-se em excesso de recursos financeiros, refletindo em ampla facilidade para importação (Furtado, 2008:56). Ao mesmo tempo, o caráter rentista da economia moldou uma sociedade e um aparelho de Estado acostumados às riquezas fáceis e divisas dependentes, em extremo, do vaivém do mercado petroleiro internacional (Lander, 2005:48; López Maya, 2006). Todavia, o conjunto destes aspectos não implica a inexistência de pobreza; ao contrário, as particularidades desta mesma economia e da utilização destes recursos produzem, igualmente em toda a América Latina, seus grandes contingentes de pobres e miseráveis em meio a enormes riquezas.

Como explicar este paradoxo? Qual implicação incide sobre a relação capital-trabalho? A resposta a estas questões requer que entendamos um pouco da economia venezuelana e sua dependência da exploração do petróleo. Vejamos.

Os enormes recursos petroleiros criaram uma sociedade parasitária, para lembrar-nos do conceito de Manoel Bomfim (1997), utilizado para caracterizar a dependência de Portugal da exploração da América portuguesa. A Venezuela sofre do mesmo mal, pois é "petróleo-dependente". Sua economia extrai riqueza do subsolo com muita facilidade e, historicamente, serviu para subsidiar a acumulação no país. O problema foi que este estímulo fácil serviu menos para a inovação e mais para a dependência do Estado petroleiro. Este foi um dos fatores que obstou o desenvolvimento industrial na Venezuela, embora não tenha sido o principal. Destarte, foram muitas as divisas conseguidas com esta exportação que, por sua vez, forçaram ao Estado a sobrevalorizar a moeda nacional com vistas a melhor utilizar os recursos advindos da 
venda do ouro negro (Furtado, 2008). Se a moeda nacional é sobrevalorizada, então, a melhor forma de obter grandes lucros é com a importação de produtos. Por consequência, era mais vantajoso consumir produtos importados do que nacionais. Assim, o setor do capital que mais se desenvolveu na Venezuela foi o comercial-financeiro, em detrimento do produtivo (Moncada, 1985). Este aspecto constituiu um ciclo vicioso que obstou o desenvolvimento da indústria no país e, por conseguinte, da classe operária. Além disso, a sobrevalorização da moeda resultou na facilidade de importação de tecnologia, feita, com frequência, pelas indústrias multinacionais, gerando a fácil substituição do trabalho vivo pelo morto. A indústria venezuelana possuía tecnologia avançada, empregava pouca mão de obra, mas mesmo assim tinha dificuldade em competir com os produtos importados. Além do mais, a crescente mecanização da extração do petróleo conduziu progressivamente ao menor emprego de força de trabalho, gerando um paradoxo, pois aquilo que mais gera capital emprega um número decrescente de trabalho vivo (Furtado, 2008).

Estes fatores tiveram implicações determinantes sobre a relação capital-trabalho no país. Só com a compreensão deles, entendemos por que a baixa taxa de juros, junto com a pouca tributação, não proporcionaram o crescimento do capital produtivo. A partir daí, existiram outras implicações para a formação da classe trabalhadora, alocada, na maior parte, no setor comercial, e não no industrial. Saber que o capital comercial emprega um número menor de trabalhadores que o industrial, e não facilita sua organização política e econômica, é deveras importante para decodificar a formação da classe trabalhadora na Venezuela. Além disso, com base na junção das características supracitadas, também deve entrar na conta o grande contingente de desempregados produzidos pelo sistema, gerando a extrema desigualdade com miséria em meio a enormes riquezas.

Nesta conjuntura, a trajetória da relação capital-trabalho na Venezuela foi pautada pela prospecção do petróleo. Como resultado deste fator, $\mathrm{o}$ não desenvolvimento de um grande parque industrial, contribuiu para algumas questões: 1) centralidade do papel do Estado na economia;2) poucas indústrias no país; 3) formação da classe operária tardia e, mesmo assim, diminuta em relação a outros países da AL; 4) dependência do trabalhador do Estado; 5) forte repressão do Estado sobre os movimentos dos trabalhadores; 6) aniquilamento de militantes revolucionários ao longo de sua história. 
Esses fatores em seu conjunto explicam a quase que completa ausência de um complexo arcabouço jurídico e de meios de fiscalização pelo Estado sobre os direitos trabalhistas até o início da década de 1990. Essa trajetória foi transformada a partir de então.

Desde meados dos anos 1980, surgem novos movimentos sociais que impõem aos governantes de turno uma série de reivindicações por meio de protestos de rua - muitos deles confrontacionais. Estas reivindicações caminham num crescendo até culminar com o Caracazo de 1989; desde então, os movimentos sociais não saem mais das ruas, impondo-se na pauta política e econômica de uma maneira jamais vista na história da Venezuela (ver López Maya, 2006, 2003; López Maya, Smilde e Stephany, 2002). Esta se constituiu na principal determinante do período do Capitalismo de Las Calles (1999-2013). É a partir destas constatações que se deve entender o incremento de direitos trabalhistas em 1991, sob o neoliberalismo.

Até as décadas de 1980-90, vimos que a Venezuela não tivera um movimento social organizado e atuante capaz de impor sua agenda ao Estado. A partir do extremo empobrecimento da população no início dos anos 1980 (entre 1986 e 1997, o índice de pobreza no país subiu de $38,88 \%$ para $48,3 \%$, e o de pobreza extrema de $17,6 \%$ para $27,6 \%$ ), há um processo crescente de reivindicações que culmina com o Caracazo de 1989. Neste, os populares saíram às ruas de maneira massiva para reivindicar diversos direitos e melhor qualidade de vida, bem como interferir, sobremaneira, na vida política do país. Desde então, constituía-se, assim, um novo ator político na Venezuela, vindo das ruas, nos termos de Margarita López Maya (2003), política de la calle.

\section{Quadro 1}

Total de Protestos entre 1989 e 1999 na Venezuela

\begin{tabular}{|l|c|}
\hline Anos & Total de Protestos \\
\hline Outubro de 1989 a setembro de 1990 & 675 \\
Outubro de 1990 a setembro de 1991 & 546 \\
Outubro de 1991 a setembro de 1992 1973 \\
Outubro de 1992 a setembro de 1993 & 87.047 \\
Outubro de 1993 a setembro de 1994 & 1.096 \\
Outubro de 1994 a setembro de 1995 & 581 \\
Outubro de 1995 a setembro de 1996 & 534 \\
Outubro de 1996 a setembro de 1997 & 550 \\
Outubro de 1997 a setembro de 1998 & 385 \\
Outubro de 1998 a setembro de 1999 & 805 \\
\hline Total da década & $\mathbf{7 . 0 9 2}$ \\
\hline
\end{tabular}

Fonte: Provea, Situação dos Direitos Humanos. Informe anual (anos respectivos) in López Maya, Smilde e Stephany (2002:10). 
O próprio presidente Hugo Chávez Frías é resultado deste acúmulo de lutas populares, que não cessaram com a sua chegada ao Executivo, mas, ao contrário, se ampliaram. Por consequência, instala-se um capitalismo de las calles de tipo legalista, pois 1) os setores hegemônicos no conjunto do movimento social são reformistas e não revolucionários, embora, tal como na Europa do pós-guerra, utilizem a palavra socialista para se autodesignarem; 2) o governo é sensível às pressões populares. Concomitantemente, muitos dos setores mais radicalizados são cooptados e institucionalizados, formando, em sua grande maioria, a base social do governo.

A Era Chávez é caracterizada como capitalismo de las calles não apenas pela presença dos movimentos sociais nas calles, mas também porque a oposição ao governo invariavelmente ganha as praças para expressar seus descontentamentos, e até ampara-se em movimentos dessa natureza para tentar tomar o poder, ou simplesmente desestabilizar o governo ${ }^{3}$. A partir daí, o governo Chávez tinha vários caminhos a seguir: 1) manter os poucos direitos trabalhistas, e atender às demandas do grande capital; 2) flexibilizar direitos, seguindo a tendência mundial; 3) incrementar direitos trabalhistas, e continuar atendendo às fortes reivindicações de rua do movimento social; 4) ou ainda, podia acabar com a coação capitalista que subordina o trabalho ao capital, atendendo reivindicações não hegemônicas no seio do movimento social.

Para melhor garantir a estabilidade social da Venezuela, seu governo optou pela terceira alternativa. Com efeito, criou novos direitos, bem como, preocupou-se em estabelecer os mecanismos punitivos para aqueles que descumprissem as normas trabalhistas. Além disso, garantiu a diminuição da jornada de trabalho. Como um plus para a classe trabalhadora, aumentou sobremaneira os investimentos sociais com o capital do Estado e da PDVSA (estatal petroleira). Tratou-se, portanto, de um governo impulsionado por novos movimentos sociais, que, pela primeira vez na Venezuela, olhou para os mais pobres prioritariamente. Ao mesmo tempo, não rompeu com a subordinação do trabalho ao capital, que apontaria para formas autogestionárias, mas ajudou a amenizar a exploração e a garantir a paz social por meio do resgate da crença de grandes parcelas dos movimentos sociais nas instituições, amplamente desgastadas desde a década de 1980.

\section{LEI DO TRABALHO SOB O GOVERNO CHÁVEZ}

A legislação do trabalho sob o governo Chávez foi caracterizada pela criação de direitos para os trabalhadores, juntamente com o incremento 
Petismo e Chavismo: Variedades de Capitalismo e de Regulação Trabalhista

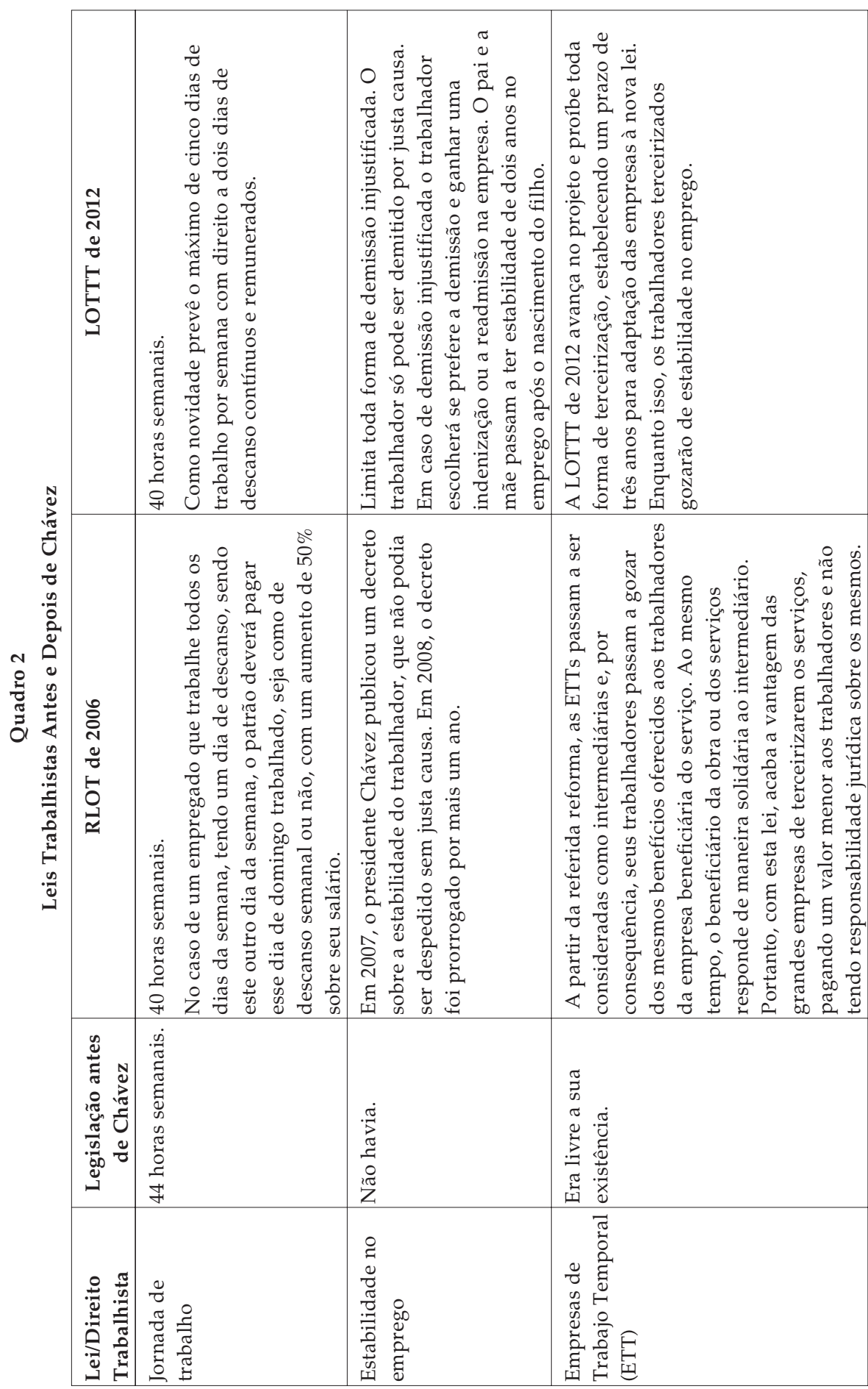




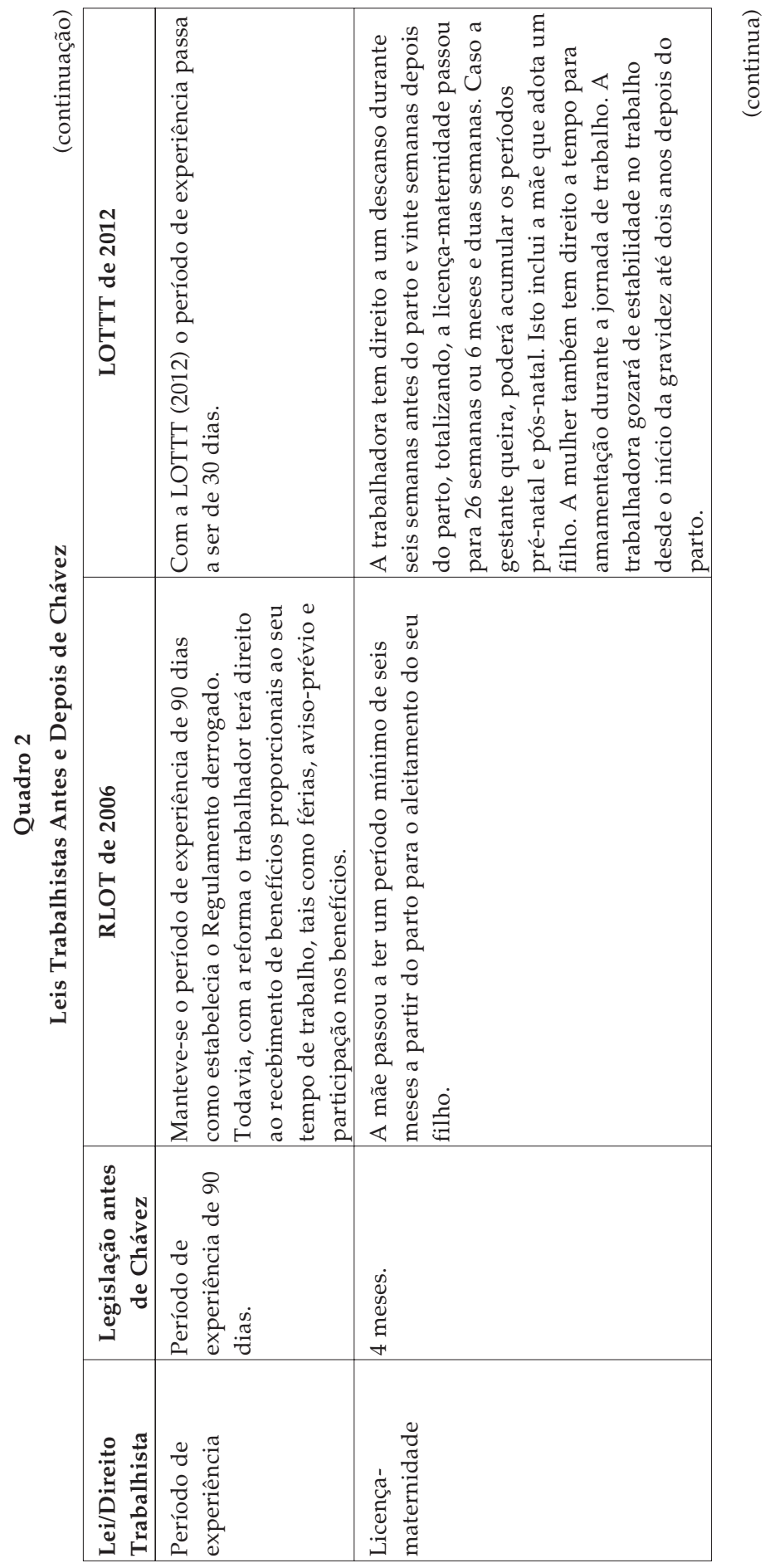


Petismo e Chavismo: Variedades de Capitalismo e de Regulação Trabalhista

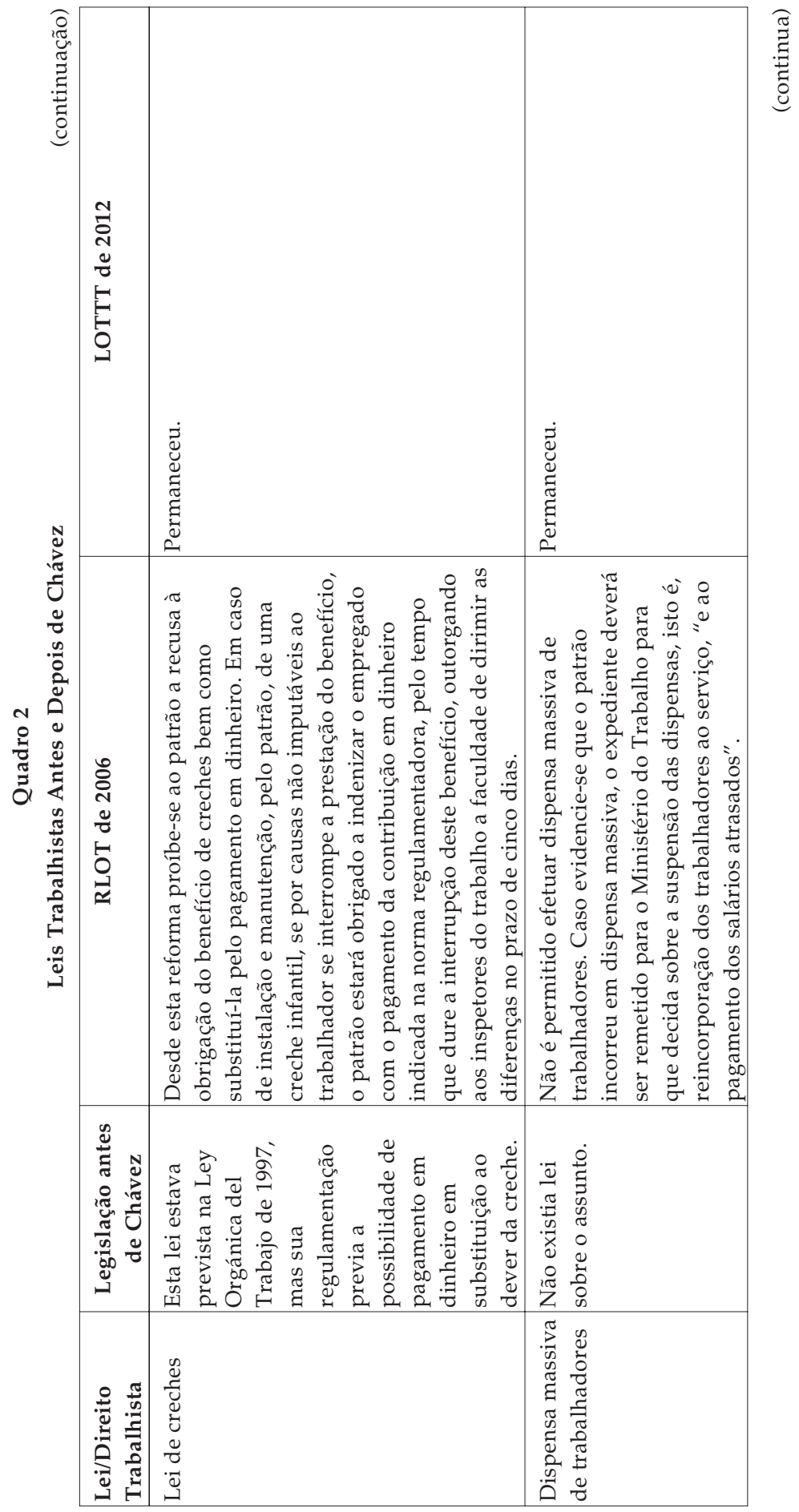

DADOS - Revista de Ciências Sociais, Rio de Janeiro, vol. 57, nํ 2, 2014 


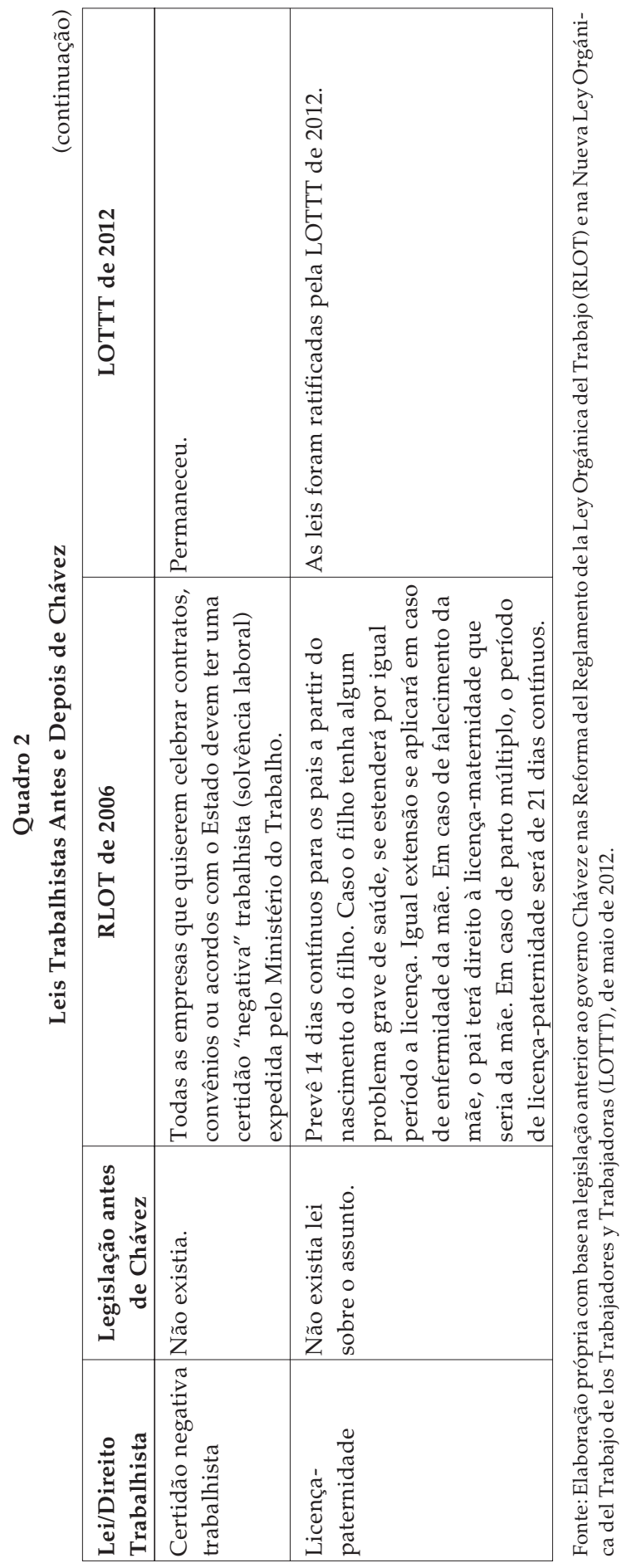


de dificuldades e/ou penalidades para aqueles que não a cumprissem. Para ilustrar essa premissa, descrevemos, dois movimentos históricos: 1) os principais pontos da reforma estabelecida em abril de 2006, quando foi promulgada a Reforma del Reglamento de la Ley Orgánica del Trabajo (RLOT); e 2) a Nueva Ley Orgánica del Trabajo de los Trabajadores y Trabajadoras (LOTTT) de maio de 2012. Optamos por trazer os principais aspectos das duas leis em seu conjunto para melhor mostrar a dimensão das reformas realizadas pelo governo Chávez ao longo de seus 13 anos. Nesse sentido, comparamos as referidas leis com a legislação anterior à chegada de Chávez ao poder. Trataremos, portanto, das duas leis como RLOT (2006) e LOTTT (2012).

O governo de Hugo Chávez Frías (1999-2012) representa o rompimento, não só com o neoliberalismo, como também com a locupletação de determinadas elites daquele país com os recursos do petróleo. Politicamente, seu governo significa o fim do pacto de Punto Fijo, de 1958, estabelecido entre os dois principais partidos do país (Acción Democrática - $\mathrm{AD}$ e $\left.\mathrm{COPEI}{ }^{4}\right)$, cuja tônica principal foi o acordo em torno da distribuição de cargos no Estado, independente de qual deles ganhasse as eleições. Na esfera econômica, representa o redirecionamento das divisas advindas da prospecção petroleira em favor de grandes investimentos sociais através de forte intervenção estatal.

Socialmente, o governo de Chávez representa a possibilidade de vida melhor para a maioria da população pobre com as missões sociais patrocinadas fundamentalmente pelos recursos do petróleo (Moraes, 2011). Sob a perspectiva das normas trabalhistas, percebemos um claro incremento de direitos, seguindo na contramão da tendência mundial. O governo Chávez, pressionado por movimentos sociais vistosos, garantiu a diminuição da jornada de trabalho, a estabilidade no emprego, o fim das empresas terceirizadas, o aumento das licenças de maternidade e paternidade e impôs sérios obstáculos para a dispensa massiva de trabalhadores. O ápice das garantias trabalhistas na Venezuela ocorre neste período. Vejamos o caso brasileiro e depois passemos para as comparações, na conclusão, entre os dois modelos.

\section{CAPITALISMO SINDICALISTA DE CONCILIAÇÃO: O CASO BRASILEIRO}

No que concerne às políticas do trabalho, o Brasil viveu um período liberal até 1930, quando se instaura um novo modelo econômico. Dava-se início à chamada Era Vargas. Neste contexto, as leis trabalhis- 
tas foram consolidadas legalmente ${ }^{5}$, juntamente com a forte intervenção do Estado na economia. Alguns teóricos denominaram o período de desenvolvimentista, outros o chamaram de corporativismo estatal. Durante a década de 1980, a força dos sindicatos e dos trabalhadores organizados resultou na conquista de novos direitos trabalhistas, alcançando o ápice com a Constituição de 1988. A greve fora o principal instrumento de luta ${ }^{6}$.

Simultaneamente, as políticas liberais voltam à cena de maneira decisiva. Estimuladas pelas principais potências mundiais, pelo grande capital, pela reorganização das associações coletivas dos empresários e pela ampla divulgação pelos meios de comunicação de suas ideias ganhando corações, mentes e, principalmente, governos. Entretanto, elas só se tornariam hegemônicas na década seguinte. Essa hegemonia foi produzida pelos seguintes fatores: 1) as vitórias políticas de coalizões de centro-direita nas eleições de 1989, 1994 e 1998; 2) exigências de organismos internacionais pelo superávit primário; 3) burocratização, cooptação e, consequentemente, enfraquecimento dos movimentos sociais; e 4) censura velada nos meios de comunicação de massa, que divulgaram as teses liberais como único caminho possível.

Por consequência, a década de 1990 foi caracterizada por: a) abertura econômica que estimulou a concorrência pelos mercados mundiais; $b$ ) programa de privatizações; c) flexibilização e/ou retirada de direitos trabalhistas; d) ampliação do contingente de desempregados. Nesse momento, o grau de mobilização dos trabalhadores, sobretudo se comparado com a década anterior, foi baixíssimo 7 . Ocorreu um processo de oligarquização e burocratização das cúpulas sindicais que previu a negociação "defensiva" em vez da "reivindicação progressiva" ${ }^{8}$. O refluxo do movimento social organizado também foi patente, tendo como principal resultado, para ambos, o fato de as lutas passarem a subordinar-se às esperanças eleitorais, transformando-as de sujeito ativo em sujeito passivo e domesticado da história.

Além do mais, no quadro de abertura econômica, as associações coletivas do empresariado passaram a reivindicar mudanças substantivas no modelo desenvolvimentista precário. Os governos atenderam a estas demandas e foi neste contexto que se encontraram as contrarreformas da Previdência, do Estado e a Trabalhista.

Particularmente, no que concerne às demandas no âmbito do Direito do Trabalho ocorridas na década de 1990, podemos afirmar que elas fo- 
ram defendidas como panaceia para os diversos problemas econômicos brasileiros na inserção na economia mundializada. Os "excessivos direitos" foram apresentados como obstáculo ao crescimento econômico e à competitividade do país no cenário internacional. A Era Vargas tinha que acabar, com vistas a diminuir o chamado "Custo Brasil". Estas foram expressões típicas do momento.

Neste contexto, contra o qual não se poderia lutar, diziam, foram realizadas diversas mudanças nas normas trabalhistas, através de Emendas Constitucionais, Leis, Medidas Provisórias (MPs), Decretos e Portarias que flexibilizam direitos e/ou prejudicam a fiscalização para o seu cumprimento, ou propõem uma negociação entre patrão e empregado sem que se recorra ao Poder Judiciário. Citamos algumas dessas medidas que alteram os direitos dos trabalhadores sob o governo de Fernando Henrique Cardoso. Elas são de três tipos: 1) alterações na jornada de trabalho - estas preconizam a adaptação total, dependente e subordinada do trabalhador aos interesses exclusivos dos empregadores (Quadro 3); 2) alterações no regime de previdência, processos de trabalho, vedação de correção automática de salários e cooperativa (Quadro 4); e 3) leis que ampliam direitos aos trabalhadores (Quadro 5).

A partir da análise dos Quadros 3, 4 e 5 percebemos que as alterações ocorreram fundamentalmente em cinco campos: 1) flexibilização da jornada de trabalho; 2) mudança nas leis previdenciárias;3) alterações nos meios processuais e da Justiça; 4) novos meios de contratação como forma de burlar direitos trabalhistas; 5) vedação de correção automática de salários. Todas estas mudanças foram em detrimento dos interesses dos trabalhadores e reivindicadas pelos empresários. As únicas medidas em favor dos interesses dos trabalhadores foram: 1) regulamentação da licença-maternidade - já prevista pela Constituição; 2) impedimento de que empregadores cobrem pelos instrumentos e outros materiais necessários para o trabalho do empregado. E, ainda, podemos incluir aqui, não como direito trabalhista, mas como política de assistência social como forma de amenizar o sofrimento de famílias pobres excluídas, o Programa Bolsa-Escola.

Por outro lado, direitos de fundamental importância como férias e o décimo terceiro salário não foram alterados, mostrando um alto grau de dependência de trajetória do modelo socialdemocrata anterior. Não obstante, o governo de Cardoso inaugura uma nova trajetória para os 


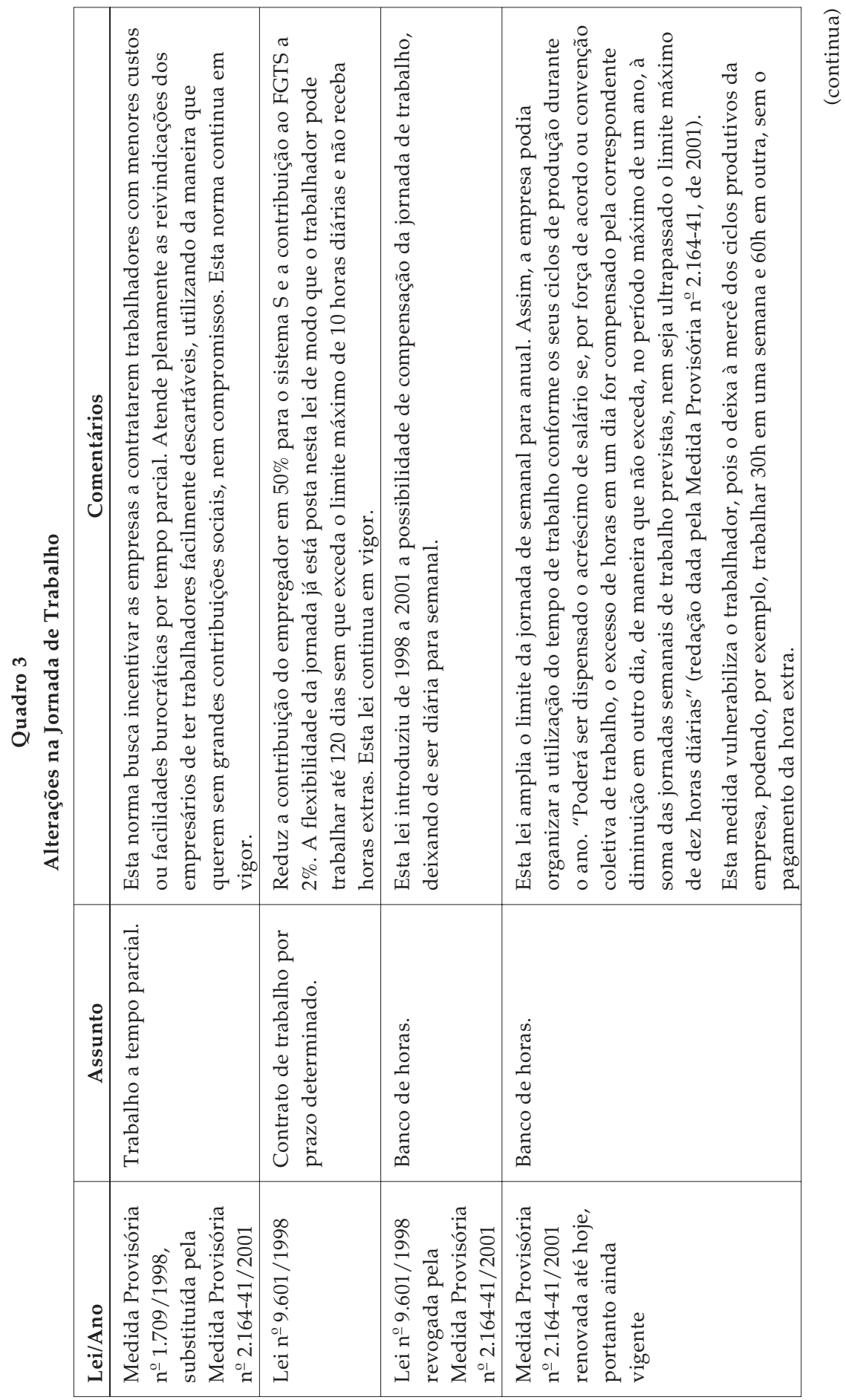


Petismo e Chavismo: Variedades de Capitalismo e de Regulação Trabalhista

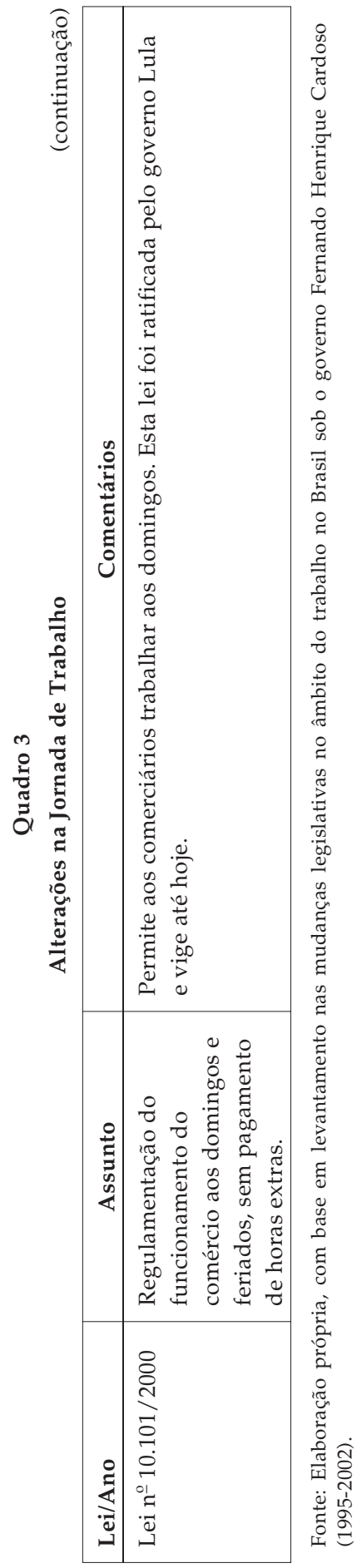

DADOS - Revista de Ciências Sociais, Rio de Janeiro, vol. 57, nำ 2, 2014 


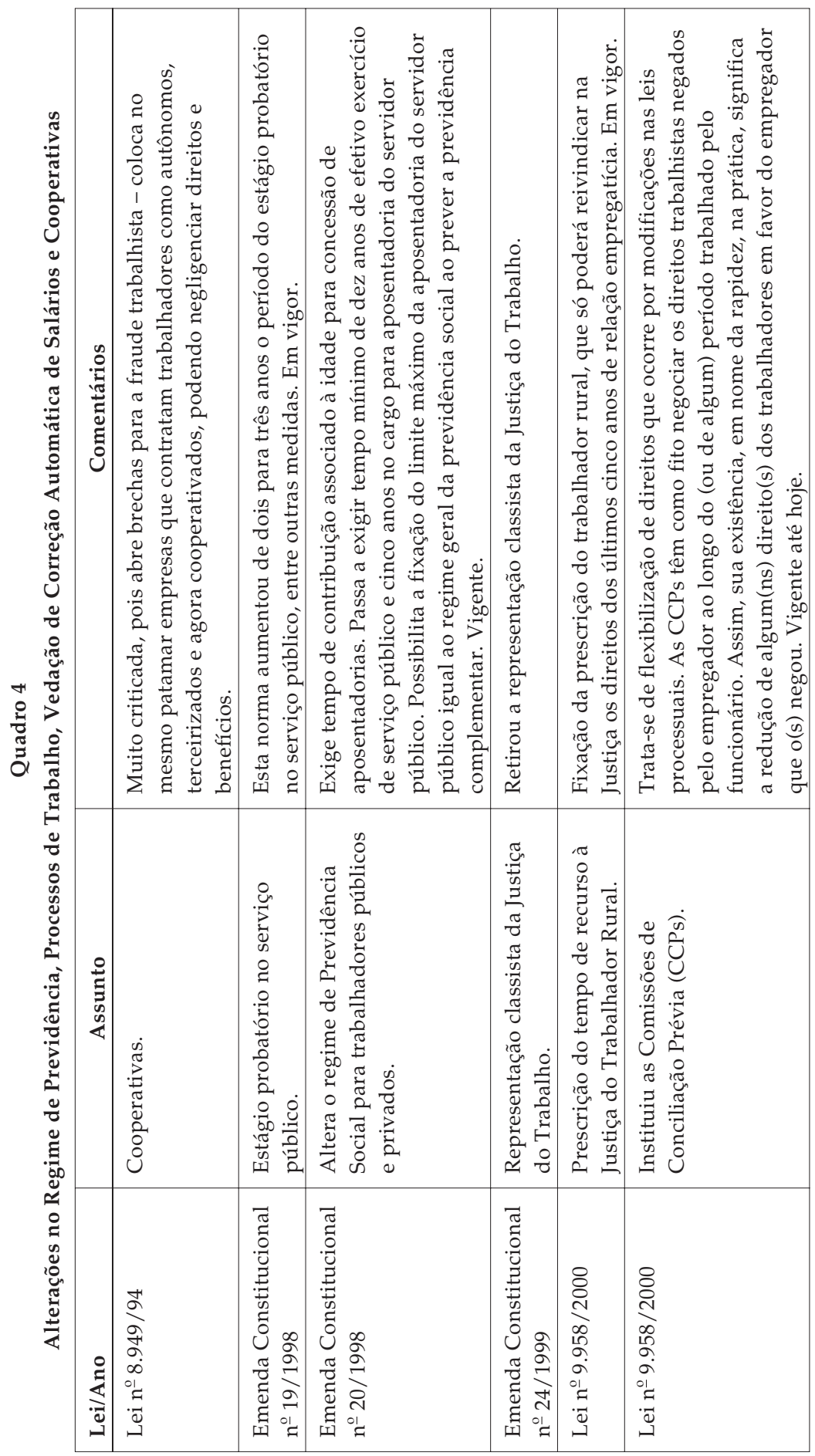


Petismo e Chavismo: Variedades de Capitalismo e de Regulação Trabalhista

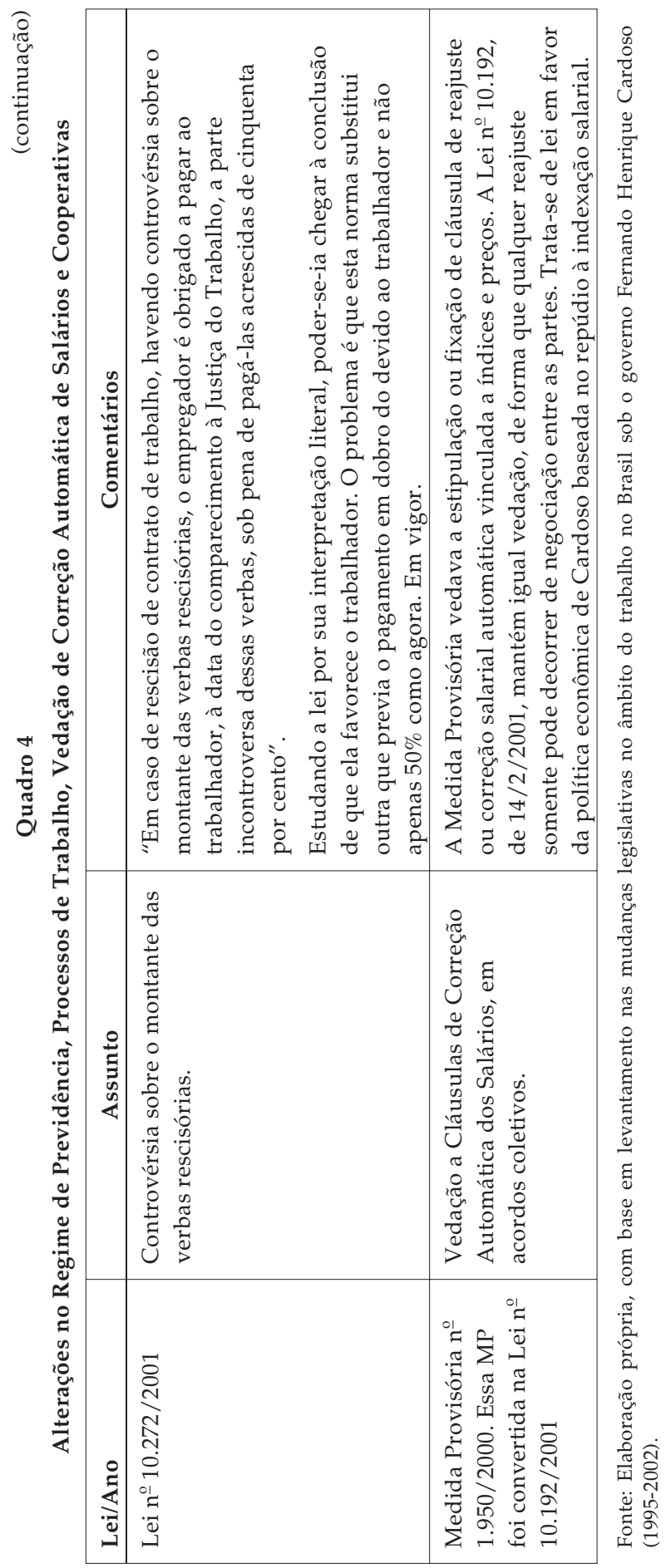

DADOS - Revista de Ciências Sociais, Rio de Janeiro, vol. 57, nำ 2, 2014 


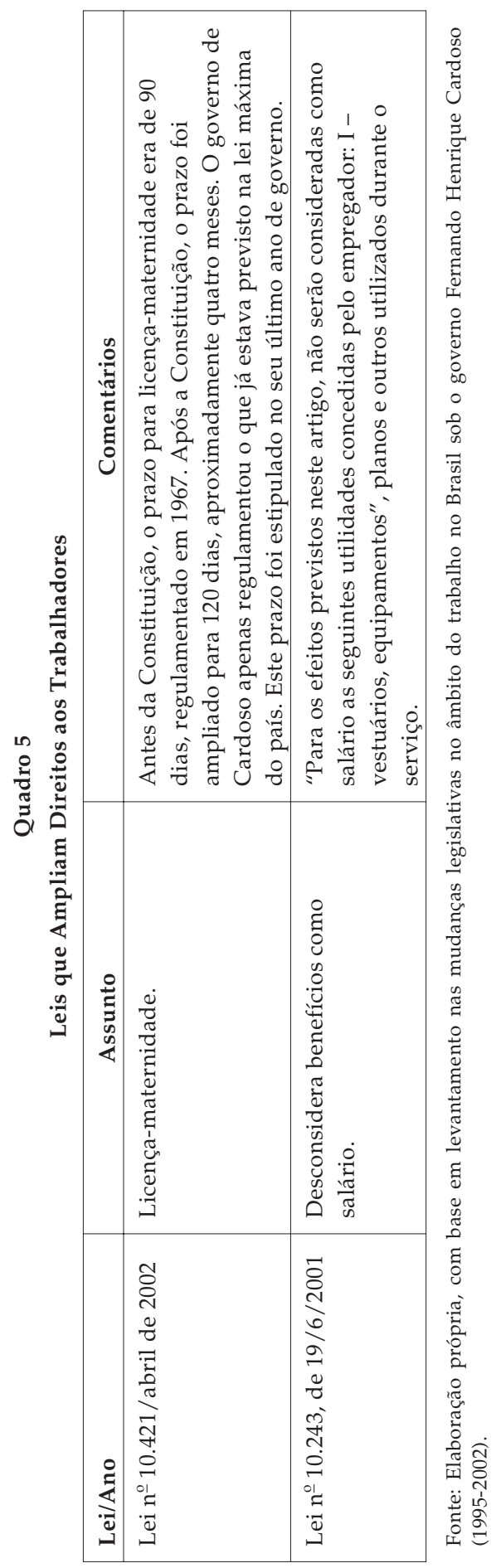


direitos trabalhistas no Brasil, baseado essencialmente na subordinação dos interesses dos trabalhadores aos dos empresários. O nosso desafio é investigar se os governos Luiz Inácio Lula da Silva e Dilma Rousseff dão continuidade ou revertem o que fora criado por aquele.

Por fim, a década de 1990, com a adoção das primeiras políticas liberalizantes, não produziu apenas perda nos direitos universais trabalhistas, mas, sobretudo aumento da miséria, das desigualdades e da violência no Brasil. O governo ainda criou alguns programas sociais focalizados, buscando amenizar as desigualdades, mas não foi suficiente para impedir o seu crescimento. Ademais, garantiu-se segurança e forte amparo às instituições bancárias, tendo este segmento alcançado os maiores lucros de sua história até então (Minella, 1997).

O período neoliberal constitui-se em grande derrota para o trabalho. $\mathrm{O}$ governo, o capital e principalmente os grandes monopólios da mídia formaram o que muitos chamaram de pensamento único, cuja principal característica foi forjar o "consenso forçado", legitimando as políticas de então. Assim, as greves foram concebidas como um acinte à sociedade como um todo. As propostas dos grevistas apareceram como meramente corporativas e contra os interesses da sociedade e do país. A Justiça atuou para considerá-las ilegais, concedendo fortes multas para os sindicatos mais combativos, diminuindo sua força de atuação. Os setores sociais que apoiavam as lutas e reivindicações populares foram completamente excluídos dos meios de comunicação e, portanto, pareciam simplesmente não existir. Por fim, em meio à liberdade garantida, os sindicatos não conseguiram incrementar direitos, tampouco aumentar sua combatividade, ao contrário: perderam garantias e força para lutar. Somadas a tudo isso, ainda ocorreram a reestruturação produtiva e as privatizações que levaram milhares de trabalhadores para a amargura do desemprego ${ }^{9}$.

Diante deste quadro adverso, Luiz Inácio Lula da Silva foi eleito presidente do Brasil. Grande parte da população depositou muita esperança no novo governo. Perscrutemos.

\section{GOVERNO LUIZ INÁCIO LULA DA SILVA (2003-2010)}

O período em questão não pode ser estudado sem que se entendam as heranças institucionais deixadas pelo governo de Fernando Henrique Cardoso. No plano econômico, tivemos a abertura e a integração com os mercados internacionais; praticamente todas as estatais privatiza- 
das ou abertas ao capital privado; a estabilidade da moeda com baixa inflação e arrocho salarial. Todos esses fatores não foram capazes de trazer o almejado por todas as economias capitalistas: o crescimento econômico. Este foi pífio, apesar de todas as medidas liberalizantes apresentarem-se a seu favor.

No plano político, o setor da sociedade mais influente sobre o governo e consequentemente mais favorecido foi o setor bancário - vide juros altos e lucros exorbitantes - e, diga-se de passagem, sem contrapartida para a sociedade.

Os empresários industriais buscaram retornar seu poder de pressão através da renovação das direções das suas associações coletivas. Suas principais demandas foram: reforma tributária, diminuição dos juros, ajuda do Estado em função da concorrência externa e diminuição dos custos trabalhistas (Boschi e Diniz, 2007; Moraes, 2011). Os sindicatos dos trabalhadores e movimentos sociais apresentaram-se praticamente esfacelados e sem poder de barganha, apesar da vitória de Lula. Esta característica resultou na desprezível atuação das associações dos vendedores de força de trabalho em pressões econômicas sobre patrões e Estado para melhoria de sua qualidade de vida, bem como pela necessária distribuição de renda - produzida substantivamente pelos proletários. A vitória do Partido dos Trabalhadores (PT) só foi possível em função do total descrédito do governo de Cardoso e de suas políticas. Lula, com propostas e postura bastante diferentes das de 1989, apresentava-se como melhor alternativa viável para as elites políticas e econômicas no intuito de assumir o comando político do país, embora subliminarmente existisse o medo da falta de governabilidade, gerada pelos "radicais" do PT.

No plano social, o Brasil figurava como o país mais desigual do mundo, com altíssimos índices de desempregados, trabalhadores em situação precária, alguns em situação análoga à de escravo, miséria, fome e a (in)consequente violência. Cabe lembrar que mais da metade da população economicamente ativa (PEA) não tinha um emprego formal e, portanto, com garantia de direitos trabalhistas e previdenciários ${ }^{10}$.

Por sua vez no plano dos direitos sociais, nosso principal objeto de pesquisa, a herança deixada pelo governo de Cardoso foi começar a desconstrução daquilo que fora criado sob o corporativismo estatal. Foram várias medidas, supracitadas, que atentaram contra os direitos dos trabalhadores. As mudanças nas leis da previdência foram para es- 
ticar a quantidade de tempo trabalhado antes de conseguir a aposentadoria. Todas essas normas foram amplamente pleiteadas pelas associações dos capitalistas (Moraes, 2009).

Diante desse quadro, vejamos o que foi realizado pelo governo Lula nos seus dois mandatos. Estudemos, portanto, as principais alterações nas leis do trabalho. Adiantamos que nem todas as leis foram contrárias aos interesses dos trabalhadores. Temos normas em prol dos trabalhadores, outras opostas aos seus interesses e, ainda, em defesa dos sindicalistas filiados às centrais sindicais existentes que os apoiam. Com efeito, dividimo-las em três tipos: 1) pró-sindicalistas; 2) leis contra o trabalho; e 3) pró-trabalho.

Podemos concluir destacando alguns aspectos importantes conduzidos pelo governo. A partir da análise das leis mencionadas anteriormente, percebemos que a maioria das mudanças atende a interesses pontuais do empresariado, dos sindicalistas e dos obstinados a entrar na carreira pública. Nos demais aspectos, podemos dizer que o governo Lula caracteriza-se por ser a continuidade do de Cardoso, assinalando um alto grau de path dependence, pelos motivos que expomos a seguir.

1. As medidas de flexibilização das leis trabalhistas realizadas sob o governo Cardoso foram renovadas pelo governo Lula, mostrando concordância com as mesmas. Isto é, este não as reverteu e, portanto, não retomou nem estabeleceu um novo projeto desenvolvimentista, tampouco combateu as políticas neoliberais.

2. As normas previdenciárias, que pioram a situação para o trabalhador, alteradas no governo de Cardoso, foram aprofundadas pelo governo Lula.

3. O governo petista criou novas formas de flexibilização das leis em detrimento dos interesses dos trabalhadores.

4. A redução da jornada de trabalho, a atualização salarial de acordo com o real custo de vida e a estabilidade no emprego não foram postas em prática pelo governo. Este não implementou a proteção contra a dispensa arbitrária, mantendo o desrespeito à Convenção 158 da Organização Internacional do Trabalho (OIT), tal como os governos anteriores.

5. Das medidas pró-trabalho do governo, nenhuma foi universal. Favoreceram-se os pescadores, as gestantes, os setores do funcionalismo 


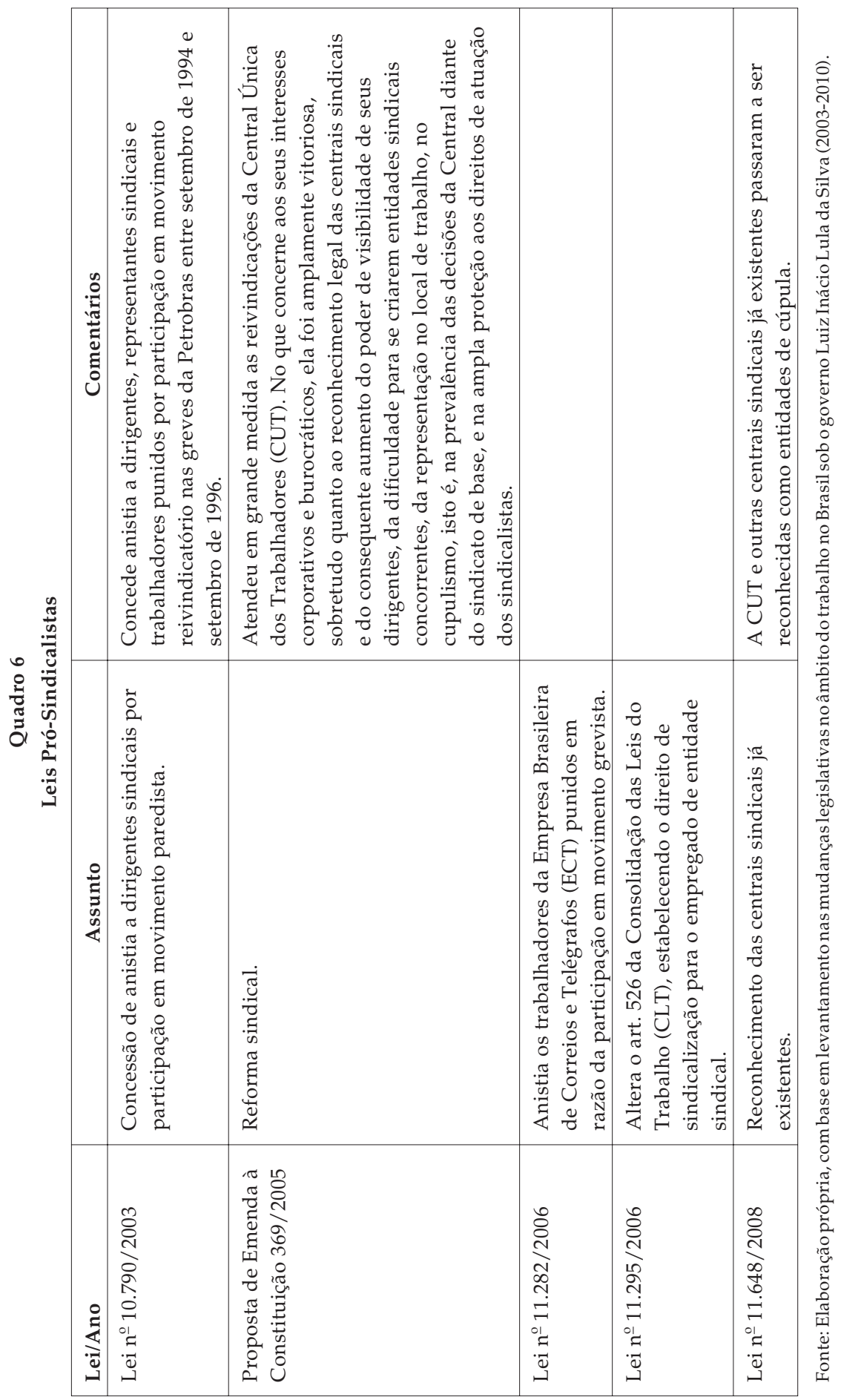


Petismo e Chavismo: Variedades de Capitalismo e de Regulação Trabalhista

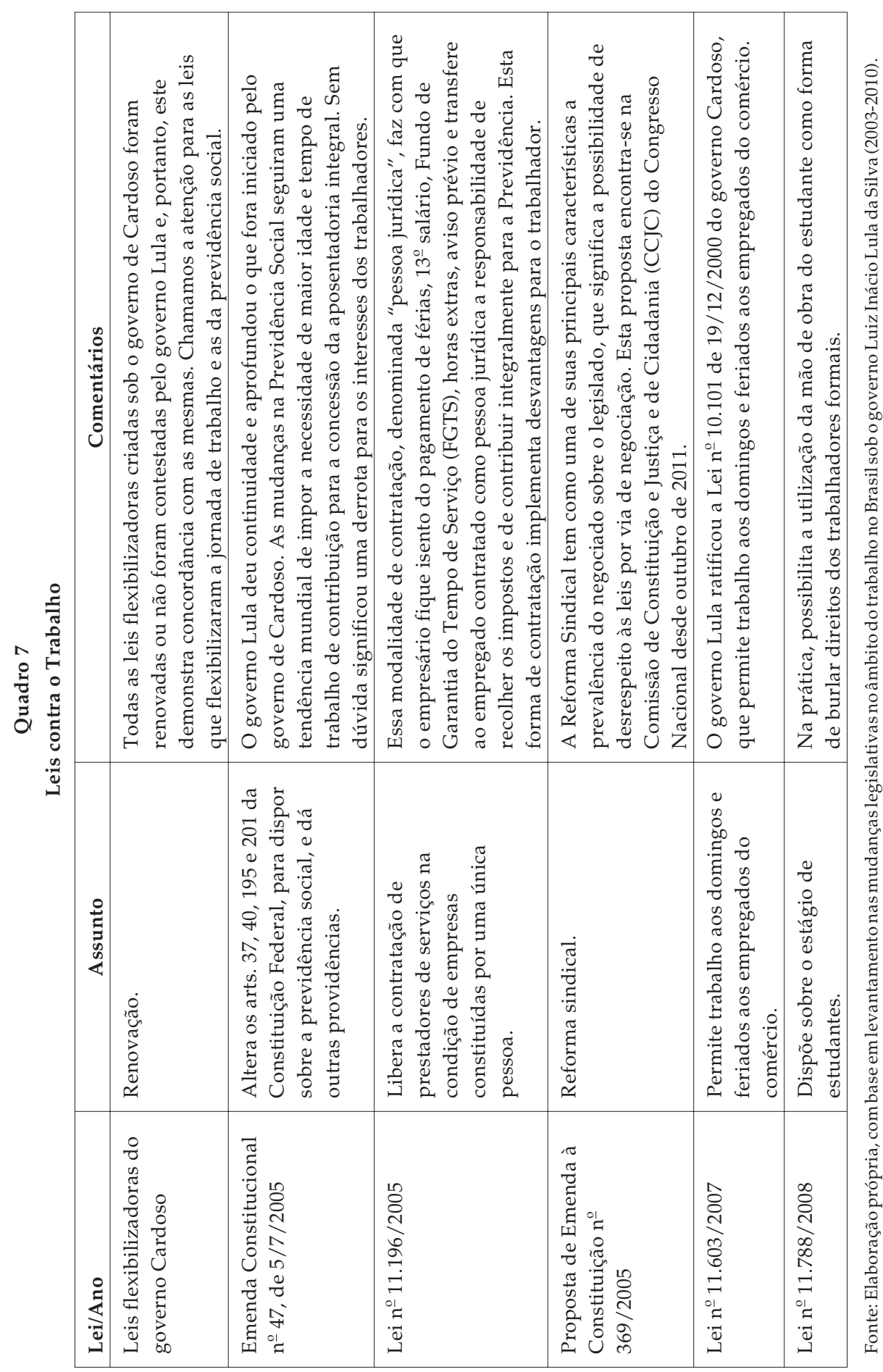

DADOS - Revista de Ciências Sociais, Rio de Janeiro, vol. 57, nำ 2, 2014 


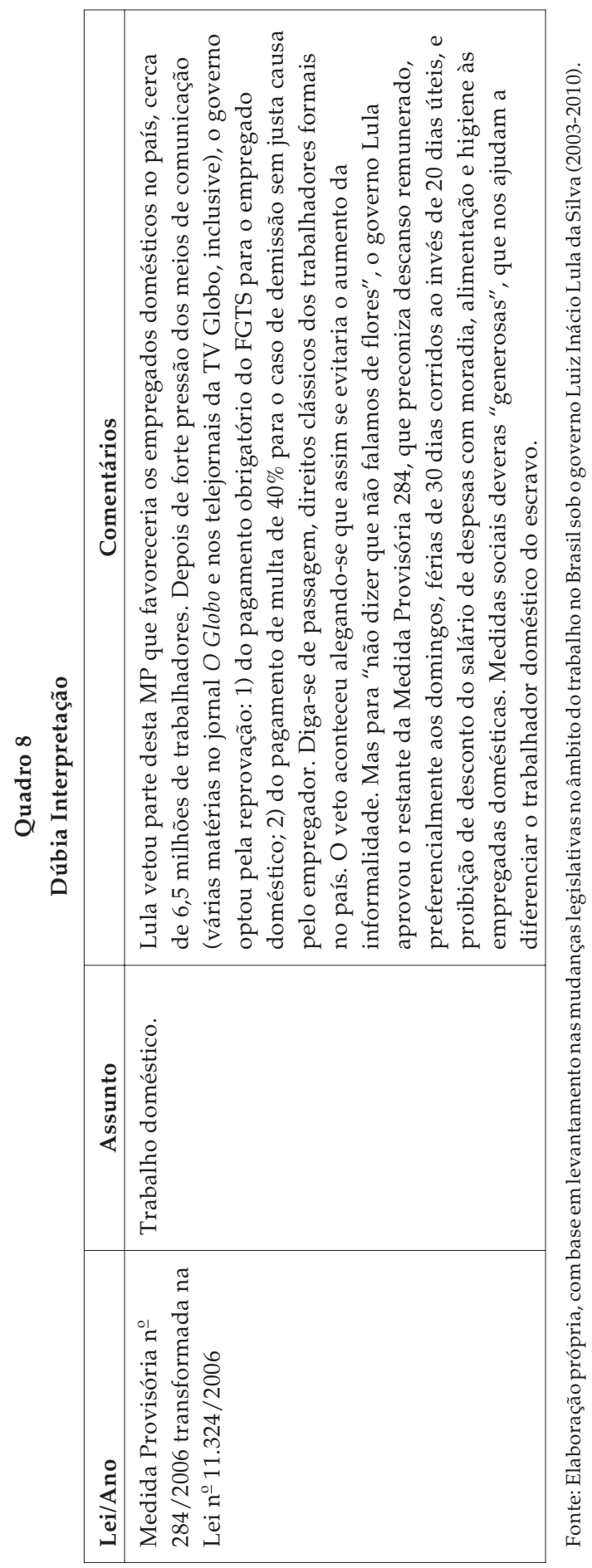


Petismo e Chavismo: Variedades de Capitalismo e de Regulação Trabalhista

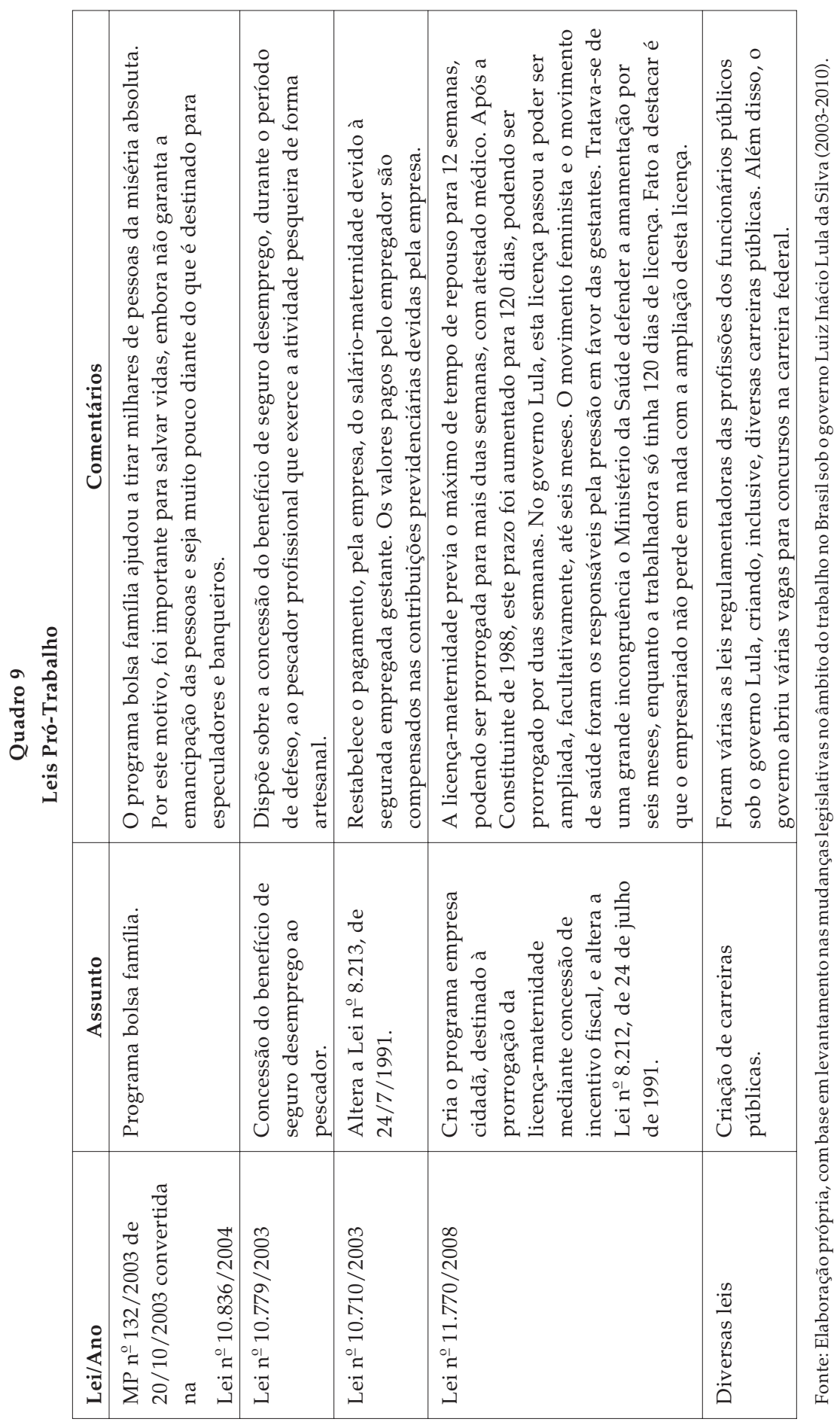

DADOS - Revista de Ciências Sociais, Rio de Janeiro, vol. 57, nำ 2, 2014 
público e principalmente as centrais sindicais, já existentes, que foram reconhecidas, enquanto diversos outros setores sociais permaneceram esquecidos. Cabe ressaltar que todas as medidas não contaram com nenhuma participação contributiva dos empresários. Em outras palavras, o governo se resguardou para que todas as medidas favoráveis ao trabalhador não gerassem nenhum ônus sobre os lucros dos capitalistas.

6. O governo Lula diferencia-se do de Cardoso ao reconhecer algumas demandas dos sindicalistas, sua principal base social, demonstrado quando anistiou sindicalistas penalizados pelo governo anterior.

7. O governo petista aumentou substantivamente o emprego público, retomando os concursos em diversas áreas. Isto foi muito positivo para parcela dos trabalhadores que almejavam uma vaga no quadro do funcionalismo na busca por estabilidade num contexto de grande desemprego e de insegurança no setor privado.

8. A conciliação entre as classes sociais foi sua principal característica, buscando unir os interesses do capital e dos sindicalistas, porém mantendo os trabalhadores submissos e sem incremento substantivo de direitos. A única ressalva que devemos fazer diz respeito ao bolsa família, que atendeu a um número considerável de pessoas, melhorando a qualidade de suas vidas e, em contrapartida, permitiu ao PT permanecer no poder por pelo menos mais dois mandatos.

9. O capital não teve nenhum ônus sob este período, muito ao contrário. O Banco Nacional de Desenvolvimento Econômico e Social (BNDES) e o próprio governo ajudaram-no com desonerações e financiamentos. As associações coletivas do empresariado não precisaram incrementar sua ação coletiva, pois o governo não apontou para ruptura do modelo de produção estabelecido, tampouco para atender aos interesses dos trabalhadores em geral.

10. Com os sindicatos e movimentos sociais fracos e sem poder de barganha, não ocorreu aumento de direitos. As grandes desigualdades sociais permaneceram, conquanto tenha acentuado o poder político dos sindicalistas da CUT junto ao governo.

A política de estabilidade econômica, por meio do controle da inflação, através de juros altos, foi idêntica ao do governo anterior. Outrossim, a central sindical criada por Lula continuou sendo sua principal base social, acrescida pelos beneficiados do bolsa família, garantindo a elei- 
ção de sua herdeira política. A dependência de trajetória no que diz respeito ao governo Cardoso foi muito grande. Não houve exorbitantes mudanças, mas, ao contrário, percebemos grandes continuidades.

Aquilo que poderia parecer uma anomalia - o governo do PT, que outrora fora a principal força de oposição à aliança Partido da Social Democracia Brasileira (PSDB)/Partido da Frente Liberal (PFL)/Partido do Movimento Democrático Brasileiro (PMDB), dar continuidade às políticas trabalhistas do governo de Cardoso - pode ser explicado com a junção de dois fenômenos: 1) o explícito recuo das forças sociais ligadas ao mundo do trabalho após o período neoliberal; 2) entender a conjuntura internacional caracterizada pela implementação de políticas contra o trabalho nos países marcados pelo enfraquecimento reivindicativo com baixa ação coletiva dos trabalhadores. Em nações sob essas características, não há grandes dessemelhanças ideológicas que se materializem em políticas públicas distintas entre partidos no poder de diferentes cores e trajetórias.

\section{GOVERNO DILMA ROUSSEFF (2011-2014)}

As heranças institucionais deixadas pelos governos anteriores e principalmente por Lula, seu padrinho político, mostraram-se grandes e praticamente irreversíveis, como denota o conceito de path dependence. No plano da macroeconomia, as mudanças foram praticamente efêmeras. Ajuste fiscal, superávit primário e poucos gastos sociais deram a tônica liberal às suas políticas. Simultaneamente, o governo garantiu diversas desonerações fiscais, redução de IPI para montadoras de automóveis e outros setores da indústria.

No plano da Previdência Social, dentre inúmeras alterações, a primeira presidente mulher regulamentou o regime complementar para os servidores públicos, instituído pela Emenda Constitucional no 20 de 15 de dezembro de 1998, do governo Cardoso. Como vimos, o governo Lula também já havia dado continuidade à contrarreforma da previdência por meio de outras emendas constitucionais. Esta regulamentação representou um grande retrocesso ao se instituir a previdência complementar para os servidores públicos federais, significando, indubitavelmente, perda de direitos para os trabalhadores.

Nos primeiros anos desse governo, a maior parte do funcionalismo federal entrou em greve, reivindicando melhores salários, condições de trabalho etc. A presidente respondeu com um aumento simplório e ao 
Quadro 10

Leis contra os Interesses dos Trabalhadores

\begin{tabular}{|l|l|l|}
\hline Lei/Ano & \multicolumn{1}{|c|}{ Assunto } & \multicolumn{1}{c|}{ Comentários } \\
\hline $\begin{array}{l}\text { Diversas leis } \\
\text { principalmente as } \\
\text { flexibilizadoras } \\
\text { da jornada de } \\
\text { trabalho }\end{array}$ & $\begin{array}{l}\text { Renovação e/ou não } \\
\text { contestação de medidas } \\
\text { flexibilizadoras. }\end{array}$ & $\begin{array}{l}\text { Todas as medidas } \\
\text { flexibilizadoras dos governos } \\
\text { Cardoso e Lula foram } \\
\text { renovadas ou não contestadas } \\
\text { pelo governo Dilma, } \\
\text { mostrando concordância com } \\
\text { as mesmas. Ver quadros } \\
\text { anteriores. }\end{array}$ \\
\hline Lei no $12.618 / 2012$ & $\begin{array}{l}\text { Institui o regime de } \\
\text { previdência complementar } \\
\text { para os servidores públicos } \\
\text { federais (...); fixa o limite } \\
\text { máximo para a concessão } \\
\text { de aposentadorias e } \\
\text { pensões pelo regime de } \\
\text { previdência especial. }\end{array}$ & $\begin{array}{l}\text { Desfavorável ao trabalhador } \\
\text { servidor público federal, pois } \\
\text { este não terá a garantia da } \\
\text { aposentadoria integral. Esta lei } \\
\text { vale para os novos servidores } \\
\text { e para os antigos que optarem } \\
\text { migrar para a previdência } \\
\text { complementar. }\end{array}$ \\
\hline
\end{tabular}

Fonte: Elaboração própria, com base em levantamento nas mudanças legislativas no âmbito do trabalho no Brasil sob o governo Dilma Rousseff (2011-2014).

mesmo tempo com uma lei de greve que amarrará praticamente todos os movimentos paredistas do funcionalismo no Brasil. Um retrocesso sem tamanho.

Enquanto alguns poucos novos direitos trabalhistas foram criados, todas as medidas de flexibilização adotadas pelos governos anteriores foram renovadas ou não questionadas, o que significa concordância com as mesmas, tal como aconteceu com a contrarreforma da Previdência Social. Vejamos as principais mudanças legislativas do período.

O governo Cardoso caracterizou-se por dar uma nova diretriz à trajetória dos direitos laborais no Brasil, iniciando a flexibilização das leis trabalhistas e previdenciárias, que atentam contra os interesses dos trabalhadores. Essas medidas impuseram um novo quadro para a relação capital-trabalho no Brasil. O governo Lula não as reverteu e ainda as renovou. A presidenta Dilma Rousseff segue a mesma linha. Por isso, não podemos dizer que os três governos representem projetos absolutamente distintos no que concerne às leis trabalhistas. Ao contrário, percebemos uma pungente continuidade e complementaridade. Do ponto de vista da path dependence, a trajetória iniciada por Cardoso é mantida por Lula e Dilma sem desvios. 
Petismo e Chavismo: Variedades de Capitalismo e de Regulação Trabalhista

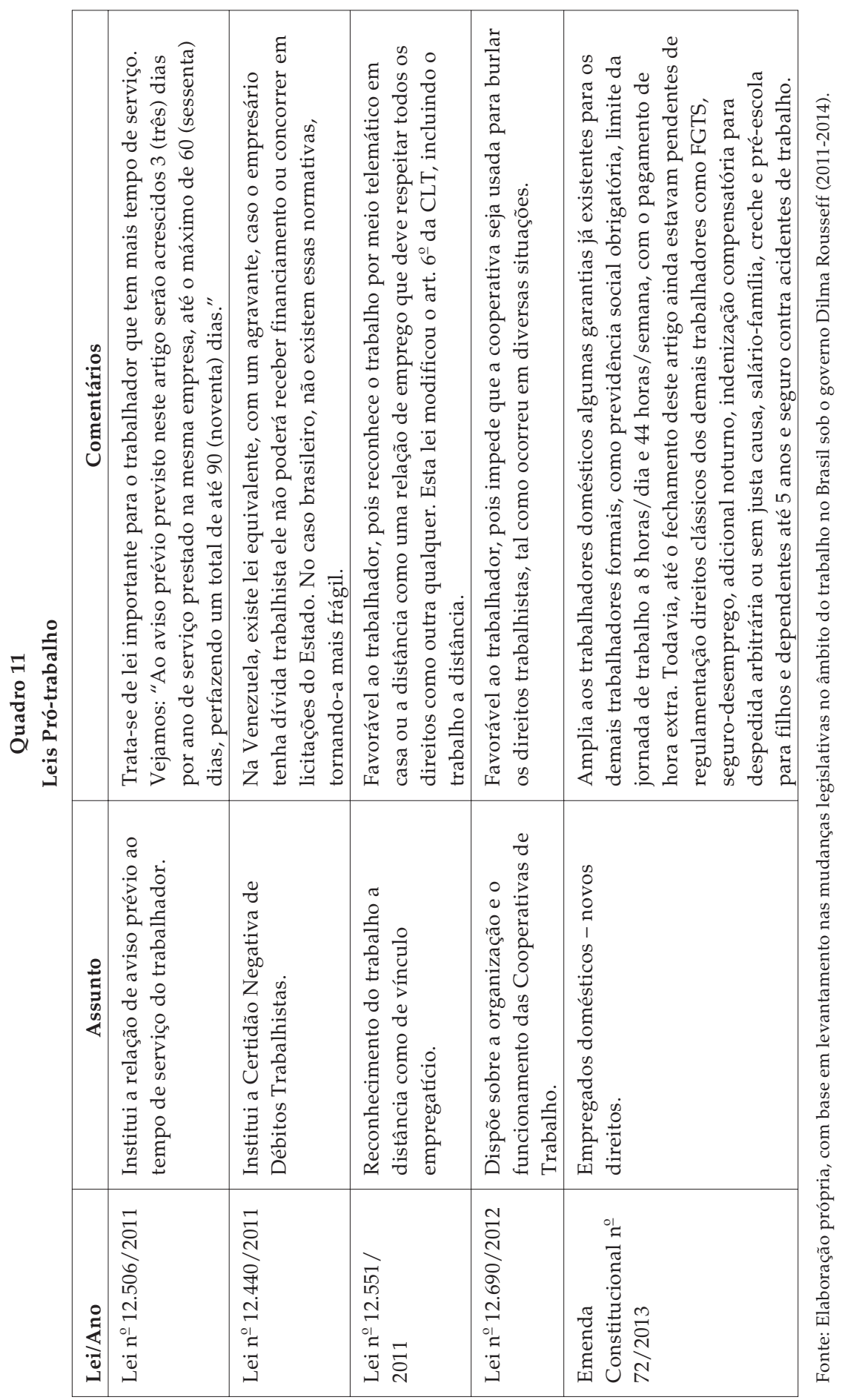

DADOS - Revista de Ciências Sociais, Rio de Janeiro, vol. 57, nำ 2, 2014 


\section{COMPARAÇÕES FINAIS}

Para efeito de conclusão, a principal constatação é de que Brasil e Venezuela produziram capitalismos muito diferentes ao longo de suas histórias. Sob o petismo e o chavismo, essas diferenças continuaram, abarcando desde as posturas dos governos, até a formação e posição, tanto dos empresários, quanto dos trabalhadores. Detectamos o curso de trajetórias bem distintas do Executivo nos dois países. Na Venezuela ocorre fortemente a implementação de políticas social-democratas para enfrentar os problemas do mercado "autorregulado". No contexto brasileiro, o petismo não lembra, nem de longe, a forte intervenção na economia dos tempos do pós-Guerra.

No Brasil, todas as esperanças depositadas tanto no presidente operário quanto na presidenta mulher não foram suficientes para que ocorresse uma ampliação significativa de direitos trabalhistas. Cardoso inaugurou, mas não aprofundou tanto as mudanças na legislação trabalhista. Lula e Dilma Rousseff expressaram a continuidade do seu governo a partir da renovação das leis criadas por ele; bem como aprofundando a flexibilização de alguns direitos. Apesar da similitude, podemos destacar três diferenças entre os governos do PSDB e do PT a partir das ações deste último: 1) ampliação dos programas assistencialistas focalizados de renda mínima; 2) reconhecimento das centrais sindicais e outras pequenas medidas pró-sindicalistas; 3) abertura de concursos públicos aumentando o quadro do funcionalismo. Essas medidas, inclusive, nem se constituem como direitos trabalhistas, mas podem ser vistas no quadro de melhora para o trabalhador. Da perspectiva da normatividade jurídica propriamente, podemos dizer, sem medo de errar, que esses governos assumem uma postura tal que parecem pertencer ao mesmo grupo político ou mesmo partido, dada a similitude e complementaridade das suas políticas públicas, formando um todo bem coerente.

Assim, podem ser vistas as sucessivas mudanças nas leis previdenciárias, seguindo estritamente a mesma tendência, o bolsa escola de Cardoso transformado em bolsa família de Lula, a licença-maternidade ampliada por aquele e continuada pelo último e, por fim, todas as flexibilizações legais de Cardoso renovadas pelos petistas. Essas medidas garantiram a governabilidade tão almejada pelo Brasil conciliador, que, contudo, subordina os interesses dos trabalhadores. 
Com base no conceito de path dependence, o neoliberalismo representa o desvio da trajetória iniciada nos anos 1930-1940. Para as mudanças legislativas no âmbito do trabalho, o governo de Cardoso foi pioneiro. Por outro lado, as mudanças estiveram e estão longe de ser amplas e irrestritas. A maior parte das garantias permaneceu intacta. Direitos como férias e décimo terceiro salário sobreviveram, por exemplo. As mudanças mais significativas ocorreram na flexibilização da jornada de trabalho e fundamentalmente na ampliação do tempo de serviço para aposentadoria integral, ambas ruins para o trabalhador. A path dependence criada no período desenvolvimentista foi deveras significativa, de modo que, embora o empresariado muito desejasse, as modificações se restringiram a flexibilizar a jornada sem que se pudesse alterar a quantidade de horas anuais.

A path dependence também se fez presente com relação aos governos da década de 1990 e os governos do século XXI. Estes não ensaiaram reverter o desvio da trajetória iniciada pelas políticas liberalizantes, não só renovando-as como até aprofundando-as. A ausência de um movimento social atuante e combativo que pressionasse os governos petistas por direitos foi a grande responsável pelas semelhanças detectadas com a coalizão PSDB / PFL/PMDB, sobretudo no que tange às políticas trabalhistas.

Na Venezuela, podemos dizer que o governo Chávez adotou um projeto nacional-desenvolvimentista, pois criou estatais; re-estatizou empresas antes privatizadas; aumentou, sobremaneira, a intervenção na economia por meio de controle de preços, ofertas de produtos a preço de custo para a população em mercados populares; e aumentou os direitos sociais e o emprego público.

O governo venezuelano, além de cessar as reformas pró-mercado, permitiu e, em alguns casos, até estimulou as reivindicações trabalhistas. Ele chegou a estatizar - por meio de indenizações - algumas firmas que não respeitaram os direitos dos trabalhadores. Também diminuiu a jornada de trabalho sem redução de salários - uma reivindicação histórica dos trabalhadores. Após a promulgação da Lei de Terras de 2001, distribuiu mais de 1 milhão de hectares de terras improdutivas entre camponeses pobres, democratizou muitas das decisões do governo sob forma de referendos e plebiscitos e ainda criou diversos programas sociais através das missões sociais de barrio adentro. Tudo foi sendo feito em pleno acordo com as leis do país e atendendo às reivindicações 
das ruas, por isso chamamos de capitalismo de las calles, que impõe uma "Revolução Legal". É importante reafirmar que Chávez foi produto e pressionado pelo crescente movimento social venezuelano despertado em fins da década de 1980, vindo num crescendo desde então.

A grande questão é que o neoliberalismo produziu efeitos absolutamente distintos para a organização da classe trabalhadora nos dois países. Enquanto na Venezuela foi produzido um vistoso movimento social, descrente dos partidos políticos e das instituições do sistema, que manifestou de maneira acintosa seus descontentamentos e desejos nas ruas, com manifestações inclusive confrontacionais; no Brasil, o período do neoliberalismo caracterizou-se pelo declínio acentuado da luta do trabalhador urbano. A greve, seu principal instrumento de pressão, praticamente inexistiu na década de 1990 e isto não significa dizer que foi resultado de ganhos de benefícios. Somente o trabalhador rural atuou ativamente nas manifestações nos anos 1990 e por isso muitos sem-terra beneficiaram-se com meios de produção. Esta foi a path dependence para o início do milênio. No Brasil, a luta do trabalhador urbano foi canalizada para as esperanças eleitorais, resultando em enorme dependência dos governantes. A grande mídia criou, inclusive, um falso consenso de que as greves, manifestações e ocupações de terra atrapalhariam a vitória eleitoral dos seus representantes, o que, por sua vez, aparecia como grande panaceia. Resultado: luta praticamente inexistente, com o movimento cooptado e institucionalizado. Daí a velha máxima: sem lutas, sem direitos.

No caso venezuelano, a dependência foi oposta, pois o clamor das ruas vinha crescendo. Ao mesmo tempo, Chávez era a expressão momentânea dos movimentos sociais que apostaram, mas não depositaram todas as suas esperanças na eleição do chefe do Executivo, pois já estavam calejados de tanta decepção. Por isso, continuaram a pressão sobre o novo governo, exigindo o cumprimento de suas promessas de campanha e impondo-lhe novas demandas. Destarte, conquistaram direitos do Estado.

Em comum, tanto o chavismo quanto o petismo caracterizaram-se por institucionalizar os movimentos proletários. No caso do Brasil, arrefecendo totalmente a luta, inclusive, do trabalhador rural. No caso da Venezuela, a luta continuou nas ruas, mas muitas delas seguiram a pauta do governo. Com efeito, afirmamos que o capitalismo de las calles não reproduziu o neoliberalismo, não criou o socialismo, mas simplesmente 
implementou políticas muito fáceis de identificar para um mínimo conhecedor da história. Trata-se de políticas desenvolvimentistas, empurradas, tal como no período do pós-guerra, por pressão do trabalho.

Ao mesmo tempo, o caso venezuelano ratifica a teoria "variedades de capitalismo", segundo a qual cada país produz um capitalismo próprio. As reformas pró-mercado na Venezuela iniciam-se em 1989, junto com os demais países da região, respeitando a onda neoliberal ditada pelos organismos internacionais (FMI, BID, BIRD) e países imperialistas (EUA, Inglaterra e outros). Todavia, a correlação de forças entre capital, trabalho e Estado produziu o que podemos chamar de anomalia do Consenso de Washington, pois incrementou direitos aos trabalhadores ao mesmo tempo que fez liberalizações para o capital.

Finalizando, os primeiros anos do século XXI têm significados diferentes nos dois países. Na Venezuela, pode ser considerado como o capitalismo de las calles, que produziu uma "Revolução Legal" - pois baseada nas leis do país e em respeito ao Legislativo e ao Judiciário, caracterizado por atender às demandas das ruas e caminhar no sentido de desconstruir aquilo imposto no neoliberalismo, com políticas desenvolvimentistas, gerando alto grau de instabilidade política, pois os interesses contrariados, embora de um número pequeno de eleitores, são muito fortes política e economicamente. Nestas condições, a Venezuela passou por um momento estritamente diferente do neoliberalismo com reversão de suas políticas.

Já no caso brasileiro, o petismo pode ser considerado como o "Capitalismo Sindicalista de Conciliação", que produziu governabilidade. $\mathrm{O}$ Executivo no Brasil, conciliador, não adotou políticas concretas em contrário ao neoliberalismo, ou que o desconstruísse, e, ainda, procurou socorrer suas instituições em crise, renovando as políticas flexibilizadoras na jornada de trabalho e na Previdência Social criadas pelo governo Cardoso. Por fim, embora petismo e chavismo não estejam muito distantes na política externa, internamente, cada qual se caracterizou por políticas extremamente distintas, sobretudo para o mundo do trabalho. Esta pesquisa comparada nos mostrou que a atuação ou não dos movimentos sociais nas ruas foi fundamental para tais diferenças.

(Recebido para publicação em fevereiro de 2013)

(Reapresentado em agosto de 2013)

(Aprovado para publicação em fevereiro de 2014) 


\section{NOTAS}

1. Nos últimos anos, a maioria das análises tem desconsiderado a variável histórica como um importante componente para o entendimento das mudanças institucionais e das variedades de capitalismo (Soskice e Hall, 2001). Esta opção não é aleatória; muitas servem para escamotear as causas de questões a que não se quer remontar, com o objetivo de favorecer determinados interesses (Coates, 2006).

2. O artigo em questão fez a opção metodológica de tratamento direto com as fontes primárias e produção de uma reflexão própria comparativa sobre o assunto; principalmente por se tratar de tema muito atual desconhecemos estudos comparativos sobre a legislação trabalhista para os casos de Brasil e Venezuela. Não obstante, alguns trabalhos tangenciam a questão e nos valeram como referência, a saber: Boschi (2007); Boyer (2005); Collier e Collier (1991); Huber (2002); Menz (2003); Sheahan (2002); Schneider (2004); Moraes (2011).

3. Assim foi, por exemplo, o golpe de Estado frustrado de 2002 organizado pela oposição ao governo Chávez.

4. Acción Democrática (AD), mais conhecido como Partido Social-Democrata; Comité de Organización Electoral Independiente (Copei), mais conhecido como Partido Social Cristiano.

5. Embora o estudo de French (2001) aponte para o amplo desrespeito da aplicação das leis.

6. Durante o ano de 1988, 1.516 categorias fizeram greve (Boletim do Dieese, janeiro-junho/1990). Fazendo uma comparação com o final da década de 1990, percebemos que, em 1997, aconteceram 648 greves, número 68,8\% menor que as 2.196 paralisações registradas em 1989. No ABC paulista, foram 10 greves em 1997. Em 1998, ocorreu apenas uma paralisação de quatro horas, no início de abril, quando os funcionários da Ford cruzaram os braços e conseguiram que a empresa alterasse a programação de férias coletivas na fábrica de São Bernardo do Campo (O Globo, 4/1 /1999, p. 22).

7. A pesquisa de Cardoso (2003) é exemplar para este aspecto.

8. Como consequência das metamorfoses no mundo do trabalho e com a adoção do toyotismo, os sindicatos passam para a defensiva, aderindo acriticamente ao sindicalismo de participação e de negociação que, em geral, aceita a ordem do capital (Antunes, 1997:33-34).

9. Ao contrário do que fora prometido, as políticas neoclássicas não ampliaram o número de empregos. Ocorreu, sim, um aumento exorbitante de desempregados, jamais visto na história do país, que a flexibilização das leis não conseguiu reverter. Ver dados do Instituto Brasileiro de Geografia e Estatística (IBGE).

10. Ver dados do IBGE. 


\section{REFERÊNCIAS BIBLIOGRÁFICAS}

ANTUNES, Ricardo. (1997), Adeus ao Trabalho? Ensaio sobre as Metamorfoses e a Centralidade do Mundo do Trabalho (4a ed.). São Paulo, Cortez.

BOMFIM, Manoel. (1997), O Brasil na América. Caracterização da Formação Brasileira (2a ed.). Rio de Janeiro, Topbooks.

BOSCHI, Renato. (2007), “Ideias de Pelica na América Latina: 'Ismos' Comparados". Insight Inteligência, ano X, no 37, pp. 126-136.

e DINIZ, Eli. (2007), A Difícil Rota do Desenvolvimento: Empresários e a Agenda Pós-neoliberal. Belo Horizonte/Rio de Janeiro, Editora UFMG/IUPERJ.

BOYER, Robert. (2005), “How and Why Capitalisms Differ”. Economy and Society, vol. 34, № 4 .

CARDOSO, Adalberto. (2003), A Década Neoliberal e a Crise do Sindicato no Brasil. São Paulo, Boitempo.

COATES, David (org.). (2006), Varieties of Capitalism, Varieties of Approaches. New York, Palgrave Macmillan.

COLLIER, Ruth B. e COLLIER, David. (1991), Shaping the Political Arena: Critical Junctures, the Labor Movement, and Regime Dynamics in Latin America. Princeton, Princeton University Press.

FRENCH, John D. (2001), Afogados em Leis: A CLT e a Cultura Política dos Trabalhadores Brasileiros. São Paulo, Editora Fundação Perseu Abramo.

FURTADO, Celso. (2008), Ensaios sobre a Venezuela: Subdesenvolvimento com Abundância de Divisas. Rio de Janeiro, Contraponto/Centro Internacional Celso Furtado.

HAGOPIAN, Frances e MAINWARING, Scott (eds.). (2005), The Third Wave of Democratization in Latin America. Advances and Setbacks. New York, Cambridge University Press.

HUBER, Evelyne (ed.). (2002), Models of Capitalism: Lessons from Latin America. Pennsylvania, University Park.

LANDER, Luis E. (2005), “Petróleo e Democracia na Venezuela: Do Fortalecimento do Estado à Sublevação Soterrada e à Insurreição Aberta", in N. Ouriques (org.), Raízes no Libertador. Bolivarianismo e Poder Popular na Venezuela (2a ed.). Florianópolis, Insular.

LANZARO, Jorge. (2006), La Tercera Ola de las Izquierdas Latinoamericanas: Entre el Populismo y la Social Democracia. Manuscrito.

LÓPEZ MAYA, Margarita. (2006), “Venezuela 2001-2004: Actores y Estrategias en la Lucha Hegemónica", in G. Caetano (org.), Sujetos Sociales y Nuevas Formas de Protesta en la Historia Reciente de América Latina. Buenos Aires, Conselho Latinoamericano de Ciencias Sociales.

. (2003), “La Protesta Popular Venezolana Entonces y Ahora: ¿Cambios en la Política de la Calle?" Revista Politeia, no 30, pp. 157-181.

; SMILDE, David e STEPHANY, Keta. (2002), Protesta y Cultura en Venezuela: Los Marcos de Acción Colectiva en 1999. Caracas, Faces/UCV. 
MAHONEY, James. (2001), The Legacies of Liberalism Path Dependence and Political Regimes in Central America. Baltimore, Johns Hopkins University Press.

MENZ, Georg. (2003), "Re-regulating the Single Market: National Varieties of Capitalism and their Responses to Europeanization". Journal of European Public Policy, no 10, pp. 532-555.

MINELLA, Ary C. (1997), "Elites Financeiras, Sistema Financeiro e o Governo FHC", in N. D. Ouriques e W. J. A. Rampinelli (orgs.), No Fio da Navalha: Crítica das Reformas Neoliberais de FHC. São Paulo, Xamã.

MONCADA, Samuel. (1985), Los Huevos de la Serpiente. Fedecámaras por Dentro. Caracas, Alianza Grafica.

MORAES, Wallace S. (2011), Brasil e Venezuela: Histórico das Relações Trabalhistas de 1889 até Lula e Chávez. Rio de Janeiro, Achiamé.

. (2009), Capitalismo Sindicalista de Conciliação e Capitalismo de las Calles: Os Casos de Brasil e Venezuela no Pós-neoliberalismo na América Latina. Tese de doutorado, Rio de Janeiro, Iuperj.

PANIZZA, Francisco (ed.). (2005), Populism and the Mirror of Democracy. London, Verso.

PIERSON, Paul. (2004), Politics in Time: History, Institutions and Social Analysis. Princeton and Oxford, Princeton University Press.

SCHNEIDER, Ben R. (2004), Business Politics and the State in Twentieth-century Latin America. New York, Cambridge University Press.

SHEAHAN, John. (2002), "Alternative Models of Capitalism in Latin America”, in E. Huber (ed.), Models of Capitalism: Lessons from Latin America. Pennsylvania, University Park.

SOSKICE, David e HALL, Peter A. (2001), Varieties of Capitalism: The Institutional Foundations of Comparative Advantage. Oxford, Oxford University Press. 
Petismo e Chavismo: Variedades de Capitalismo e de Regulação Trabalhista

\section{LEGISLAÇÃO}

Ley Orgánica del Trabajo de los Trabajadores y Trabajadoras (LOTTT) (2012).

Constitución de la República Bolivariana de Venezuela (1999).

Ley Orgánica del Trabajo de la República Bolivariana de Venezuela (1997).

Ley del Seguro Social de la República Bolivariana de Venezuela (2006).

Consolidação das Leis Trabalhistas (CLT) (1943) com atualizações até 2012.

"Gaceta Oficial no 38.426 de fecha 28 de abril de 2006 da República Bolivariana de Venezuela" - Reglamento de la Ley Orgánica del Trabajo de 25 de abril de 2006. 


\title{
RESUMO
}

Petismo e Chavismo: Variedades de Capitalismo e de Regulação Trabalhista no Brasil e na Venezuela

O objetivo deste artigo é discutir as variedades de capitalismo na América Latina e verificar se a chegada de governos de base popular alterou o curso das políticas trabalhistas implementadas após os anos 1990. Mais precisamente trata-se da discussão sobre a regulação laboral sob os governos petistas (2003-2013) e chavista (1999-2013) respectivamente no Brasil e na Venezuela. A pesquisa tem como propósito analisar como esses governos trataram a herança institucional deixada pelos antecessores neoliberais. Utilizamos a teoria de variedades de capitalismo e o conceito de path dependence para o entendimento da questão. Percebemos que a força dos movimentos sociais nas ruas foi determinante para as diferentes posturas assumidas tanto pelo petismo, como pelo chavismo.

Palavras-chave: regulação trabalhista; América Latina, Brasil; Venezuela

\begin{abstract}
Petismo and Chavismo: Varieties of Capitalism and Labor Regulation in Brazil and Venezuela

This article discusses varieties of capitalism in Latin America and examines whether the ascension to power of governments elected with a broad popular constituency changed the course of labor policies implemented after the 1990s. More specifically, it approaches labor regulation implemented under the governments led by the Workers' Party (PT) in Brazil (2003-2013) and the Chaves government in Venezuela (1999-2013). The main goal of the research is to verify how these governments dealt with the institutional legacies of their neoliberal predecessors. The theory of varieties of capitalism and the concept of path dependency were used in order to understand this issue. It was noticed that the strength of social movements on the streets were determinant in shaping the positions adopted by the government of the PT and Chávez.
\end{abstract}

Keywords: labor regulation; Latin America, Brazil; Venezuela 


\section{RÉSUMÉ}

Pétisme et Chavisme: Variétés de Capitalisme et de Régulation du Travail au Brésil et au Venezuela

Dans cet article, on examine les variétés de capitalisme en Amérique Latine et on évalue si l'arrivée de gouvernements à base populaire a modifié le cours des politiques du travail mises en place dans les années 1990. Plus précisément, il y est menée une discussion sur la régulation du travail sous le gouvernement du PT (Parti des Travailleurs) (2003-2013) au Brésil et sous celui de Chávez (1999-2013) au Venezuela. Le but de la recherche a été d'examiner comment ces gouvernements ont traité l'héritage institutionnel laissé par leurs prédécesseurs néo-libéraux. Pour bien saisir la question, on se sert de la théorie des variétés de capitalisme et du concept de path-dependence. On se rend compte que la force des mouvements sociaux de rue a été décisive dans les différentes attitudes adoptées aussi bien par le pétisme que par le chavisme.

Mots-clés: régulation du travail; Amérique Latine; Brésil; Venezuela

\section{RESUMEN}

Petismo y Chavismo: Variedades de Capitalismo y de Regulación Laboral en Brasil y Venezuela

El objetivo de este artículo es discutir las variedades de capitalismo existentes en América Latina y verificar si la llegada de gobiernos de base popular cambió el rumbo de las políticas laborales implementadas tras los años 1990. Más precisamente, se discute la regulación laboral bajo los gobiernos petistas (2003-2013) y chavista (1999-2013), respectivamente, en Brasil y en Venezuela. La investigación tien como propósito principal analizar cómo estos gobiernos trataron la herencia institucional dejada por los antecesores neoliberales. Utilizamos la teoría de variedades de capitalismo y el concepto de path dependence para entender la cuestión. Observamos que la fuerza de los movimientos sociales en las calles fue determinante para las diferentes posturas que asumieron tanto el petismo como el chavismo.

Palabras clave: regulación laboral; América Latina, Brasil; Venezuela 